\title{
Genetic Diversity of Bartonella spp. in Wild Mammals and Ectoparasites in Brazilian Pantanal
}

\author{
Keyla Carstens Marques de Sousa ${ }^{1} \cdot$ Renan Bressianini do Amaral ${ }^{1} \cdot$ Heitor Miraglia Herrera ${ }^{2} \cdot$ Filipe Martins Santos $^{2}$. \\ Gabriel Carvalho Macedo ${ }^{2}$. Pedro Cordeiro Estrela de Andrade Pinto ${ }^{3}$. Darci Moraes Barros-Battesti ${ }^{1}$. \\ Rosangela Zacarias Machado ${ }^{1} \cdot$ Marcos Rogério André ${ }^{1,4}$
}

Received: 29 September 2017 / Accepted: 27 December 2017 / Published online: 8 January 2018

(C) Springer Science+Business Media, LLC, part of Springer Nature 2018

\begin{abstract}
The present work aimed to investigate the genetic diversity of Bartonella in mammals and ectoparasites in Pantanal wetland, Brazil. For this purpose, 31 Nasua nasua, 78 Cerdocyon thous, 7 Leopardus pardalis, 110 wild rodents, 30 marsupials, and 42 dogs were sampled. DNA samples were submitted to a quantitative real-time PCR assay (qPCR). Positive samples in qPCR were submitted to conventional PCR assays targeting other five protein-coding genes. Thirty-five wild rodents and three Polygenis (P.) bohlsi bohlsi flea pools showed positive results in qPCR for Bartonella spp. Thirty-seven out of 38 positive samples in qPCR were also positive in cPCR assays based on fts $Z$ gene, nine in $n u o G$-cPCR, and six in gltA-cPCR. Concatenated phylogenetic analyses showed that two main genotypes circulate in rodents and ectoparasites in the studied region. While one of them was closely related to Bartonella spp. previously detected in Cricetidae rodents from North America and Brazil, the other one was related to Bartonella alsatica, Bartonella pachyuromydis, Bartonella birtlesii, Bartonella acomydis, Bartonella silvatica, and Bartonella callosciuri. These results showed that at least two Bartonella genotypes circulate among wild rodents. Additionally, the present study suggests that Polygenis (P.) bohlsi bohlsi fleas could act as possible Bartonella vectors among rodents in Pantanal wetland, Brazil.
\end{abstract}

Keywords Bartonellaceae $\cdot$ Wild carnivores $\cdot$ Fleas $\cdot$ qPCR $\cdot$ Wild rodents $\cdot$ Brazilian wetland

\section{Introduction}

Bartonella species comprise facultative, fastidious, gramnegative intracellular bacteria belonging to the alpha- 2 class

Electronic supplementary material The online version of this article (https://doi.org/10.1007/s00248-017-1138-0) contains supplementary material, which is available to authorized users.

Marcos Rogério André

marcos_andre@fcav.unesp.br

1 Faculdade de Ciências Agrárias e Veterinárias, Universidade Estadual Paulista (Unesp), Jaboticabal, SP, Brazil

2 Universidade Católica Dom Bosco, Campo Grande, MS, Brazil

3 Laboratório de Ecologia Animal, Universidade Federal da Paraíba, Rio Tinto, PB, Brazil

4 Laboratório de Imunoparasitologia, Departamento de Patologia Veterinária, Faculdade de Ciências Agrárias e Veterinárias Júlio de Mesquita Filho (UNESP), Campus de Jaboticabal, Via de Acesso Prof. Paulo Donato Castellane, s/n, Zona Rural, CEP: 14884-900, Jaboticabal, São Paulo, Brazil of Proteobacteria [1]. The transmission of these agents occurs mainly through blood-sucking arthropod vectors. Seventeen Bartonella species are known to be etiological agents of several diseases in animals and humans [2].

Rodents are considered as natural reservoirs for several Bartonella species. The association between rodents and Bartonella shows great importance, since these animals present persistent and subclinical bacteremia for long periods of time. Infections by a wide variety of Bartonella species have been reported in many different rodent species worldwide [3].

In Brazil, Bartonella spp. have been detected in synanthropic rodents in Salvador city, state of Bahia (Atlantic forest biome) [4] and in wild rodents from periurban areas from Mato Grosso do Sul and Pernambuco states $[5,6]$. Recently, different Bartonella genotypes have been detected in wild and synanthropic rodents from different Brazilian biomes [7]. In addition to this, Bartonella spp. have been detected among cats [8], dogs [9], and wild carnivores $[10,11]$ in Brazil. 
Due to the lack of information about the epidemiology and transmission routes of Bartonella spp. among wildlife in Brazil, the present study aimed to investigate the occurrence of Bartonella in wild mammals, domestic dogs, and ectoparasites in Brazilian Pantanal wetland.

\section{Materials and Methods}

\section{Study Area}

The fieldwork was conducted at the Nhumirim ranch $\left(56^{\circ} 39^{\prime}\right.$ $\left.\mathrm{W}, 18^{\circ} 59^{\prime} \mathrm{S}\right)$, located in the central region of the Pantanal, municipality of Corumbá, state of Mato Grosso do Sul, central-western Brazil (Fig. 1). This region is characterized by a mosaic of semideciduous forest, arboreal savannas, seasonally flooded fields covered by grasslands with dispersed shrubs, and several temporary and permanent ponds. The Pantanal is the largest Neotropical floodplain, and it is well known for a rich biodiversity. Two well-defined seasons are recognized: a rainy summer (October to March) and a dry winter (April to September) [12-14].

\section{Biological Sampling}

Between the years of 2013 and 2015, four field expeditions were performed in August 2013, October 2013, August 2014, and March 2015. Free-ranging Cerdocyon thous (crab-eating fox), Nasua nasua (coati), and Leopardus pardalis (ocelot) were caught using a Zootech $^{\circledR}$ (Curitiba, PR, Brazil) model wire box live trap $(1 \times 0.40 \times 0.50 \mathrm{~m})$, which was made with galvanized wire mesh and baited with a piece of bacon every afternoon. Twenty traps were placed on the ground at 2-km intervals, left open during $24 \mathrm{~h}$ and checked twice a day for 12 days. The animals were immobilized with an intramuscular injection of zolazepan and tiletamine at dosages of $8 \mathrm{mg} /$ $\mathrm{kg}$ for ocelots and $10 \mathrm{mg} / \mathrm{kg}$ crab-eating foxes and coatis. Blood samples were collected by puncture of the cephalic vein stored in Vacutainer ${ }^{\circledR}$ containing EDTA and stored at $20^{\circ} \mathrm{C}$ until DNA extraction.

Small mammals (rodents and marsupials) were captured using live traps (Sherman ${ }^{\circledR}$, H. B. Sherman Traps, Tallahassee, FL, USA, and Tomahawk ${ }^{\circledR}$ Tomahawk Live Traps, Tomahawk, WI, USA) baited with a mixture of banana, peanut butter, oat, and sardines. Traps were set up for seven consecutive nights along linear transects, placed on the ground at 10-m intervals and alternating between trap type in two field expeditions (August 2014 and March 2015). The total capture effort was 200 traps-nights, equally distributed in two expeditions (August 2014 and March 2015). The rodents and marsupials had to be euthanized in order to perform the identification of the animal's species, based on external and cranial morphological characters and karyological analyses. The animals were firstly anesthetized with an intramuscular injection of ketamine (10-30 mg/kg) with acepromazine $(5-10 \mathrm{mg} / \mathrm{kg}$ ) for rodents (proportion 9:1), or xylazine $(2 \mathrm{mg} / \mathrm{kg}$ ) for marsupials $(1: 1)$. After anesthesia, the animals were euthanized with potassium chloride, which doses ranged from 75 to $150 \mathrm{mg} / \mathrm{kg}$. Spleen

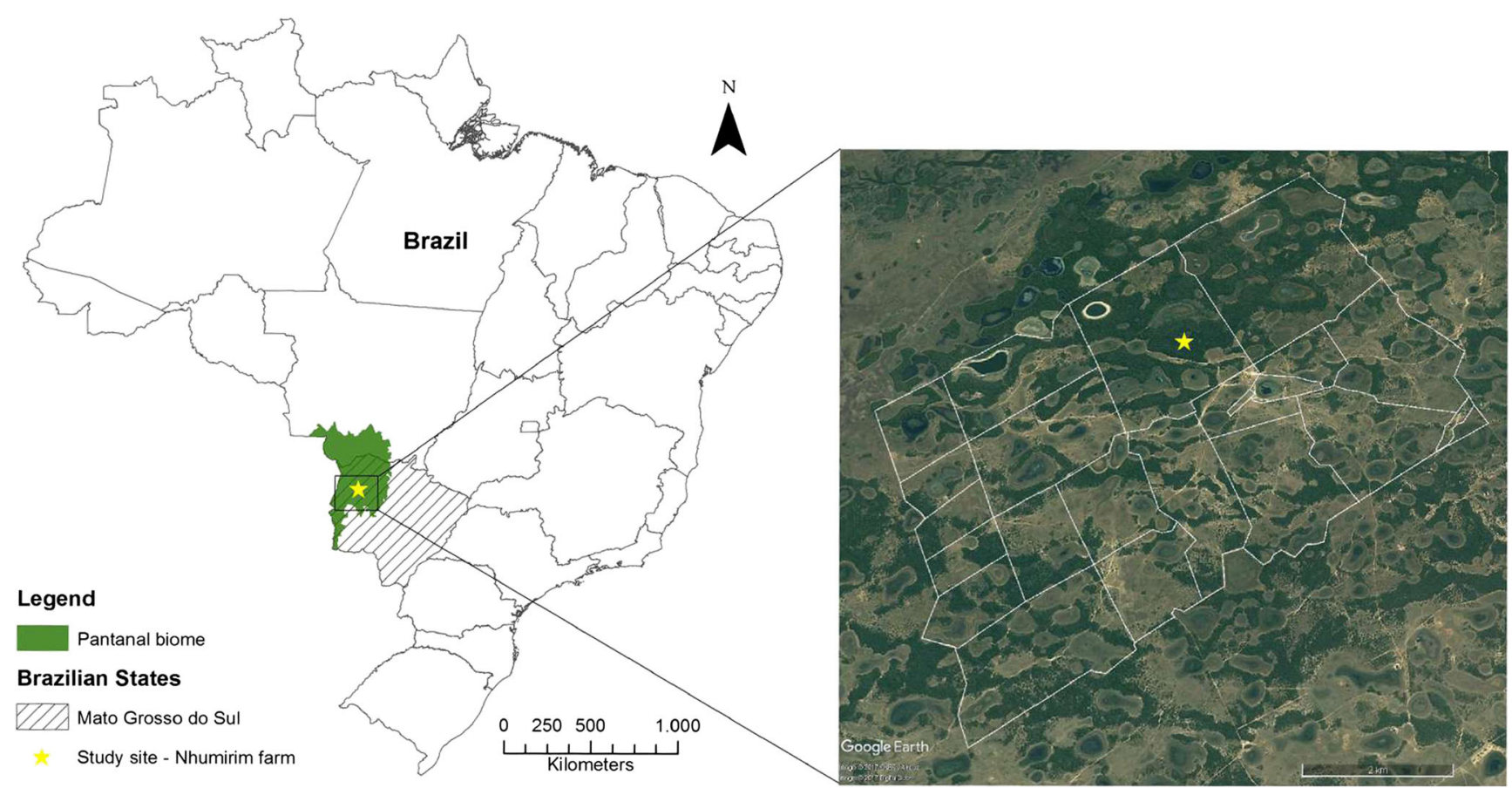

Fig. 1 Capture sites. Map of Mato Grosso do Sul State, central-western Brazil, showing the Pantanal region, where animals samples were collected in the present study 
samples were collected and stored in absolute alcohol $\left(\operatorname{Merck}^{\circledR}\right.$, Kenilworth, NJ, USA).

A total of 256 animals were captured, including 158 carnivores, including 78 C. thous, 31 N. nasua, 7 L. pardalis, 110 wild rodents (77 Thrichomys fosteri, 25 Oecomys mamorae, and 8 Clyomys laticeps), and 30 wild marsupials (14 Thylamys macrurus, 11 Gracilinanus agilis, 4 Monodelphis domestica, and 1 Didelphis albiventris). Additionally, 42 blood samples from domestic dogs cohabiting the same studied area were collected [12-14].

\section{Ectoparasite Identification}

Ticks and fleas found parasitizing the sampled animals were detected by inspection of the skin and carefully removed by forceps or manually. The identification was performed using a stereomicroscope (Leica ${ }^{\circledR}$ MZ 16A, Wetzlar, Germany) and following taxonomic literature for adult tick genera [15, 16] and Amblyomma spp. nymphs [17]. Amblyomma spp. larvae could not be identified to the species level considering the insufficient literature available until now. The identification of fleas was performed following previously described taxonomic keys [18].

One thousand five hundred eighty-two ticks parasitizing the sampled mammals were collected, including 1033 (65.2\% [115 adults and 918 nymphs]) Amblyomma sculptum Berlese specimens, 241 (15.2\% [78 adults and 163 nymphs]) Amblyomma parvum Aragão specimens, 32 (2\%) Amblyomma ovale Koch adults, 1 (0.06\%) Amblyomma tigrinum Koch adult, 1 (0.06\%) Rhipicephalus (Boophilus) microplus (Canestrini) adult, 1 (0.06\%) Rhipicephalus sanguineus s.1. (Latreille) adult, 4 (0.2\%) Amblyomma auricularium (Conil) nymphs, and 269 (17\%) Amblyomma larvae. Furthermore, a total of 80 Polygenis (Polygenis) bohlsi bohlsi (Wagner) fleas were also collected [12-14].

\section{Molecular Analysis}

DNA was extracted from $200 \mu \mathrm{L}$ of each whole blood (158 wild carnivores and 42 domestic dogs) and $10 \mathrm{mg}$ of spleen (140 small mammals) samples using the DNeasy Blood \& Tissue Kit (Qiagen ${ }^{\circledR}$, Valencia, CA, USA), according to the manufacturer's instructions. The total number of individual ticks and pools were 523, of which 228 (43.5\%) were from adults, $256(48.9 \%)$ pooled nymphs, and $39(7.4 \%)$ from pooled larvae. DNA extraction from ticks was processed in pools for nymphs (up to 5 individuals) and larvae (up to 10 individuals), while the adults were processed individually. The collected ticks were pooled according to individual host animals. A total of 39 pooled fleas samples were submitted to DNA extraction. The fleas DNA extraction was also performed in pools consisting of up to five individuals. Ticks and fleas were macerated and submitted to DNA extraction, using the same kit before mentioned [12-14].

In order to verify the presence of amplifiable DNA in the samples, internal control PCR assays targeting fragments of mammalian glyceraldehyde-3-phosphatedehydrogenase (GAPDH) [19], ticks mitochondrial 16S rRNA [20], and fleas cytochrome-c oxidase subunit I (Cox-1) [21] genes were performed (Table 1). All 298 DNA animal samples amplified the predicted product for GAPDH gene. Out of 523 sampled ticks, 31 (5.9\% [23 A. parvum adults, 4 A. sculptum adults, 1 A. ovale adult, 1 A. parvum nymph, and 2 pooled Amblyomma larvae]) showed negative results for the tick mitochondrial 16S rRNA gene and were excluded from subsequent analyses. Only one flea DNA sample did not amplify the predicted product for cox-1 and was also excluded from subsequent analyses [12-14].

Firstly, a previously described broad range quantitative real-time PCR (qPCR) protocol based on nuoG gene was used aiming to detect and quantify Bartonella spp. DNA copies (number of copies/ $\mu \mathrm{L}$ ) [8]. Serial dilutions were performed aiming to construct standard curves with different concentrations of plasmid DNA (pIDTSMART - Integrated DNA Technologies $)\left(2.0 \times 10^{7}\right.$ to $2.0 \times 10^{0}$ copies $\left./ \mu \mathrm{L}\right)$, which encoded an 83-bp Bartonella henselae-nuoG gene fragment. The number of plasmid copies was determined in accordance with the formula $(\mathrm{Xg} / \mu \mathrm{L} \mathrm{DNA} /[$ plasmid size $(\mathrm{bp}) \times 660]) \times$ $6.022 \times 10^{23}$ xplasmid copies/ $\mu L$. Each qPCR assay was performed including duplicates of each DNA sample. All the duplicates showing $\mathrm{Cq}$ difference values higher than 0.5 were re-tested. Amplification efficiency (E) was calculated from the slope of the standard curve in each run using the following formula $\left(E=10^{-1} /\right.$ slope $)$. To determine the limit of detection from the qPCR assay, the standard curves generated by 10 fold dilutions were used to determine the amount of DNA that could be detected with $95 \%$ of sensitivity. All positive samples in qPCR assays were submitted to previously described conventional PCR (cPCR) assays targeting five other proteincoding genes, namely gltA (750 bp) [22], ftsZ (600 bp) [24], nuo G (400 bp) [23], ribC (420 bp) [24], and rpoB (585 bp) [9] (Table 1). The reaction products were purified using Silica Bead DNA Gel Extraction Kit (Thermo Fisher Scientific ${ }^{\circledR}$, Waltham, MA, USA). Purified amplified DNA fragments from positive samples were submitted to sequence confirmation in an automatic sequencer (ABI Prism 310 Genetic Analyzer - Applied Byosystem/Perkin Elmer).

\section{Bioinformatics/Phylogenetic Analysis}

The sequences obtained from positive samples were first submitted to a screening test using Phred-Phrap software version 23 [25] to evaluate the electropherogram quality and to obtain consensus sequences from the alignment of the sense and antisense sequences. The BLAST program was used to 


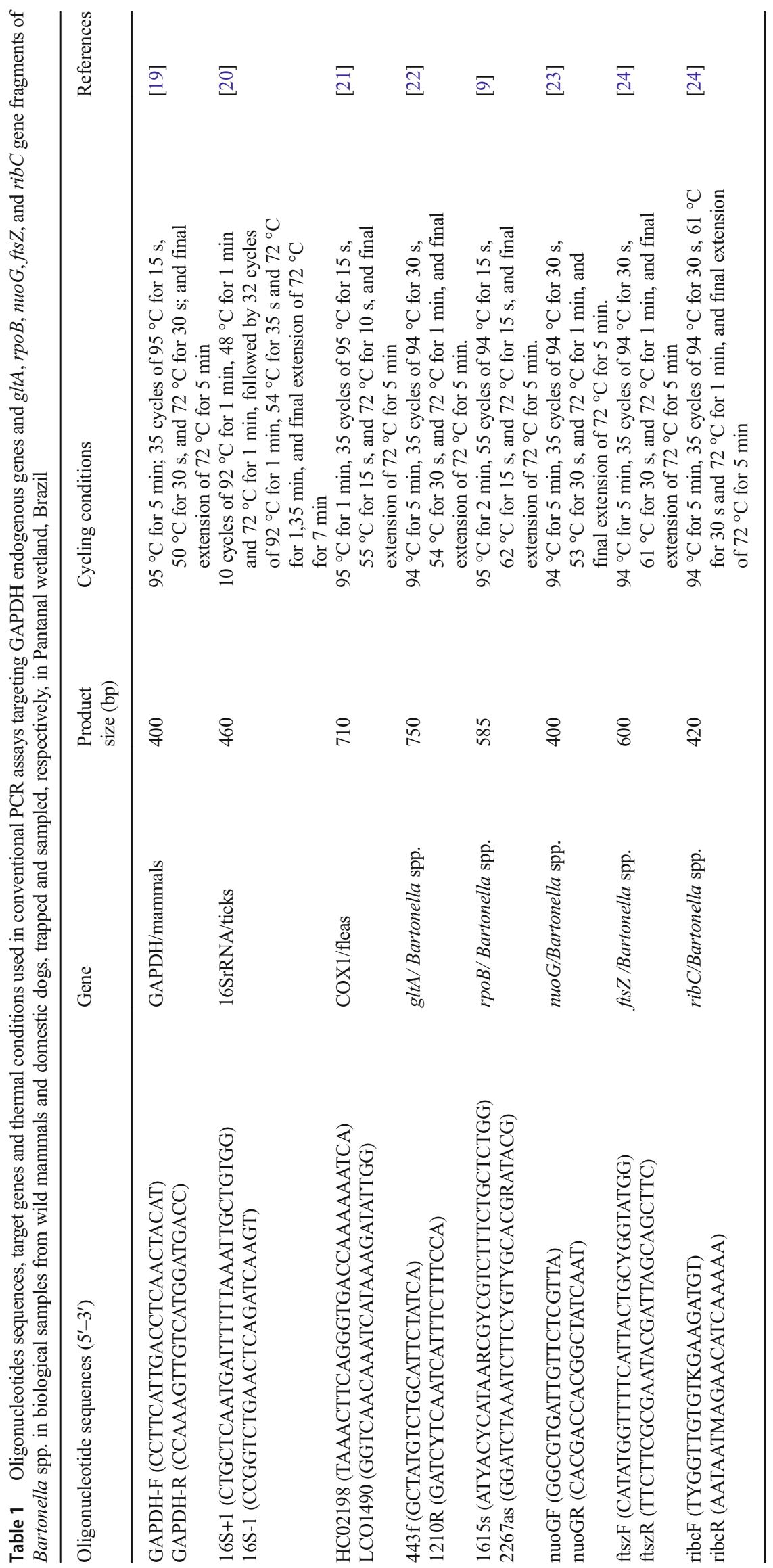


analyze the sequences of nucleotides (BLASTn), aiming to browse and compare with sequences previously deposited in GenBank international database. All sequences that showed appropriate quality standards and identity with Bartonella spp. were deposited in the GenBank international database. Samples showing positive results for more than one protocol had their sequences concatenated, using the fragment merger software, version 1 [26]. The sequences were aligned with sequences retrieved from GenBank using MAFFT software, version 7 [27].

The best evolutionary model was selected by the program jModelTest2 (version 2.1.6) on XSEDE [28], under the Akaike information criterion (AIC) [29]. Phylogenetic inference was based on Bayesian Inference (BI). The BI analysis was performed with MrBayes 3.1.2 [30]. Markov chain Monte Carlo (MCMC) simulations were run for $10^{9}$ generations with a sampling frequency of every 100 generations and a burn-in of $25 \%$.

Additionally, analysis of nucleotide polymorphisms of sequences obtained in the present study was performed. The sequences were aligned using Clustal/W [31]. The number of haplotypes, haplotype diversity (Hd), nucleotide diversity $(\mathrm{Pi})$, and number of variable sites were determined using the program DnaSP 5, version 5.10.01 [32].

\section{Results}

Thirty-five (31.8\%) wild rodents and three (7.8\%) Polygenis (P.) bohlsi bohlsi flea pools (collected from three T. fosteri wild rodents) showed positivity in qPCR assays for Bartonella spp. based on the nuoG gene. None of sampled C. thous, N. nasua, L. pardalis, marsupials, domestic dogs, and ticks showed positivity in qPCR assays for Bartonella spp. based on the nuoG gene. Among Bartonella-positive rodents, $30(85.7 \%)$ belonged to T. fosteri species and five (14.2\%) belonged to $O$. mamorae species. The Bartonella-positive fleas in qPCR assays were not collected from any positive wild rodent.

The number of copies of Bartonella-nuoG fragment $/ \mu \mathrm{L}$ ranged from $1.33 \times 10^{0}$ to $2.61 \times 10^{6}$. The efficiency and correlation coefficient of qPCR reactions ranged from 91.1 to $101.3 \%$ and 0.948 to 0.998 , respectively. The quantification mean (copies of Bartonella-nuoG fragment $/ \mu \mathrm{L}$ ) of all reactions were $6.913 \times 10^{4}$, ranging from $1.33 \times 10^{0}$ to $2.61 \times$ $10^{6}$. The quantification mean between the groups of hosts were: $T$. fosteri $=3.73 \times 10^{2}$ copies $/ \mu \mathrm{L}\left(1.33 \times 10^{0}-3.58 \times\right.$ $\left.10^{3}\right)$, O. mamorae $=5.23 \times 10^{5} \mathrm{copies} / \mu \mathrm{L}\left(1.57 \times 10^{1}-2.61 \times\right.$ $10^{6}$ ) and Polygenis (P.) bohlsi bohlsi $=3.11 \times 10^{1} \mathrm{copies} / \mu \mathrm{L}$ $\left(2.77 \times 10^{1}-3.51 \times 10^{1}\right)$.

Thirty-seven samples $(97.3 \%)$ out of 38 qPCRpositive samples for Bartonella also showed positivity in cPCR based on the fts $Z$ gene, of which 29 belonged to $T$. fosteri species, 5 belonged to $O$. mamorae species, and 3 belonged to Polygenis (P.) bohlsi bohlsi flea species. Four $O$. mamorae and two flea pools positive samples in fts $Z$ cPCR also showed positivity in cPCR based on gltA gene. In addition to this, 9 T. fosteri positive samples in fts $Z$ cPCR also showed positivity in cPCR based on nuoG gene (Fig. 2). None of sampled animals or arthropods was positive in cPCR assays based on rpoB and ribC genes (Fig. 2). All gltA, fts $Z$, and $n u o G$ sequences obtained from positive animals and fleas were deposited in the GenBank international database under the following accession numbers: KX578719, KX827420, KY273622-KY273657, and KY304482-KY304486.

The BLAST analysis of a 750-bp fragment of Bartonella gltA gene obtained from four $O$. mamorae spleen samples showed $96 \%$ identity with the American isolated R-phy1 Bartonella sp. (Z70010). The Bartonella sp. gltA sequences obtained from flea samples showed $95 \%$ identity with a Bartonella spp. sequence obtained from a wild Brazilian rodent (KX086733). On the other hand, the Bartonella ftsZ sequences $(600 \mathrm{bp})$ obtained from the same four O. mamorae spleen samples showed $91 \%$ identity with B. vinsonii subsp. berkhoffii (CP003124). Twenty-nine Bartonella fts $Z$ sequences obtained from $T$. fosteri spleen samples showed $94-96 \%$ identity with B. alsatica (AF467763). Three Bartonella fts $Z$ sequences obtained from flea pools showed $92 \%$ identity with a Bartonella spp. sequence obtained from a wild Brazilian rodent (KX036239). The BLAST analysis of a 400-bp fragment of Bartonella nuoG gene obtained from nine T. fosteri spleen samples showed 94-95\% identity with B. alsatica (EF659935) (Table 2).

The concatenated phylogenetic analysis of Bartonella based on gltA and fts $Z$ genes showed that eight Bartonella $g l t A+f t s Z$ sequences obtained from $O$. mamorae wild rodents and four Bartonella gltA $+f t s Z$ sequences obtained

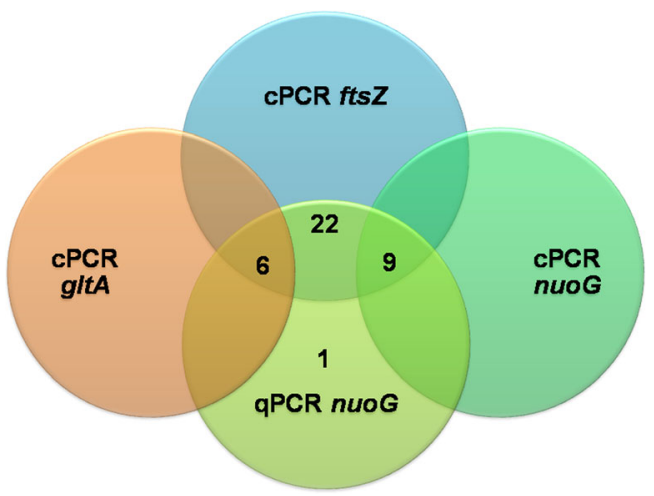

Fig. 2 Venn diagram showing the co-positivity between qPCR based on $n u o G$ gene and cPCR assays based on $f t s Z, n u o G$, and gltA genes 
from Polygenis (P.) bohlsi bohlsi flea pools were pooled in the same branch of Bartonella sequences obtained from Brazilian wild rodents previously deposited in the GenBank, with clade support of 100 , based on BI analysis and GTR+G+I evolutionary model for both genes alignments (Fig. 3). Besides, the concatenated phylogenetic analysis of Bartonella based on gltA and fts $Z$ genes showed that Bartonella spp. sequences obtained from $O$. mamorae wild rodents and Polygenis (P.) bohlsi bohlsi pools from the present study were closely related to Bartonella genotypes detected in Sigmodon hispidus in the USA and Bartonella genotypes detected in Brazilian wild rodents previously deposited in the GenBank (Fig. 3). Additionally, the concatenated phylogenetic analysis of Bartonella based on nuoG and fts $Z$ genes showed that 18 nuoG $+f t s Z$ Bartonella sequences obtained from T. fosteri wild rodents were grouped in the same clade of B. alsatica, B. pachyuromydis, B. birtlesii, $B$. acomydis, $B$. silvatica, and $B$. callosciuri, with high clade support of 99, based on BI analysis and GTR+G+I (for $f t s Z$ aligment) and $\mathrm{TrN}+\mathrm{I}+\mathrm{G}$ (for $n u o G$ aligment) evolutionary models (Fig. 4).

Among the six Bartonella gltA sequences analyzed, four different haplotypes were found, showing $\mathrm{Pi}=$ 0.02889 , hd $=0.8667$, and $\mathrm{K}=16.6667$. The haplotypes \#2 and \#4 were formed by two sequences each, while the haplotypes \#1 and \#3 were formed by only one sequence each. The haplotypes \#1, \#2, and \#3 were formed only by gltA sequences obtained from $O$. mamorae and the haplotype \#4 was formed by sequences obtained from fleas samples. Analyzing the alignment of 37 Bartonella $f_{s t} Z$ sequences, four different haplotypes were also found, with $\mathrm{Pi}=0.03523$, hd $=0.413$, and $\mathrm{K}=$ 9.3018. The haplotype\#1 was formed by only one Bartonella $f_{s t} Z$ sequence obtained from $T$. fosteri, the haplotype \#2 was formed by 28 sequences also obtained from T. fosteri, the haplotype \#3 was formed by five sequences obtained from $O$. mamorae, and the haplotype \#4 was formed by three sequences obtained from fleas samples. The Bartonella nuoG alignment did not present variable sites, so it was not possible to observe any polymorphism or nucleotide diversity between the sequences of this gene.

\section{Discussion}

The present study showed the presence of Bartonella DNA in wild rodents' spleen samples and Polygenis (P.) bohlsi bohlsi fleas collected from rodents in Brazilian Pantanal wetland.

The found occurrence of Bartonella spp. among wild rodents sampled in the present study was higher (31.8\%) than that found among synanthropic rodents (19.2\%) in the city of Salvador, state of Bahia, northeastern Brazil [4] and in wild rodents $(0 \%)$ sampled in the semi-arid region of Pernambuco [6], northeastern Brazil, but similar to that found in a previous recent study involving wild rodents $(34.4 \%)$ sampled in southern Pantanal [7]. However, the occurrence of Bartonella infection among wild rodents in Pantanal biome in the present study was lower than that found in wild rodents $(42.8 \%)$ in peri-urban areas from the same state where the present study was performed [5]. A closer contact among wild rodents from peri-urban areas with different host species (including domestic animals) and arthropods could explain the differences observed in prevalence rates.

Based on the phylogenetic analysis, a genotype closely related to Bartonella spp. (phylogenetic group A and strain R-phy1) detected in Cricetidae rodents from North America [1, 33] and Brazil [7] was detected in O. mamorae rodents, also belonging to Cricetidae family. On the other hand, based on the gene-sequence-based criteria for species definition in bacteriology [34], the genotype detected in this present study may correspond to a new CandidatusBartonella species. A previous experimental study reported high host specificity of

Table 2 Maximum identity of gltA, ftsZ, and nuoG Bartonella spp. referring to the full length sequences detected in wild rodents and fleas sampled in Brazilian Pantanal, by BLAST analysis

\begin{tabular}{|c|c|c|c|c|c|}
\hline Host & $\begin{array}{l}\text { Biological } \\
\text { sample }\end{array}$ & $\begin{array}{l}\text { Number of sequences } \\
\text { analyzed }\end{array}$ & $\begin{array}{l}\text { Product size } \\
\text { (bp) }\end{array}$ & $\begin{array}{l}\text { Target } \\
\text { gene }\end{array}$ & $\%$ identity by BLAST ${ }^{\circledR}$ analysis \\
\hline O. mamorae & Spleen & 4 & 679 & gltA & Bartonella sp. strain R-phy1 (Z70010) 96\% \\
\hline $\begin{array}{l}\text { Polygenis (P.) bohlsi } \\
\quad \text { bohlsi }\end{array}$ & Flea & 2 & 670 & gltA & $\begin{array}{l}\text { Uncultured Bartonella sp. wild rodent Brazil } \\
\text { (KX086733) 95\% }\end{array}$ \\
\hline O. mamorae & Spleen & 4 & 550 & $f t s Z$ & B. vinsonii subsp. berkhoffii (CP003124) 91\% \\
\hline T. fosteri & Spleen & 30 & 545 & $f t \mathrm{sZ}$ & B. alsatica (AF467763) 94-96\% \\
\hline $\begin{array}{l}\text { Polygenis (P.) bohlsi } \\
\quad \text { bohlsi }\end{array}$ & Flea & 3 & 570 & $f t \mathrm{sZ}$ & Bartonella spp., wild rodent Brazil (KX036239) 96\% \\
\hline T. fosteri & Spleen & 9 & 350 & пиоG & Bartonella alsatica (EF659935) 94-95\% \\
\hline
\end{tabular}




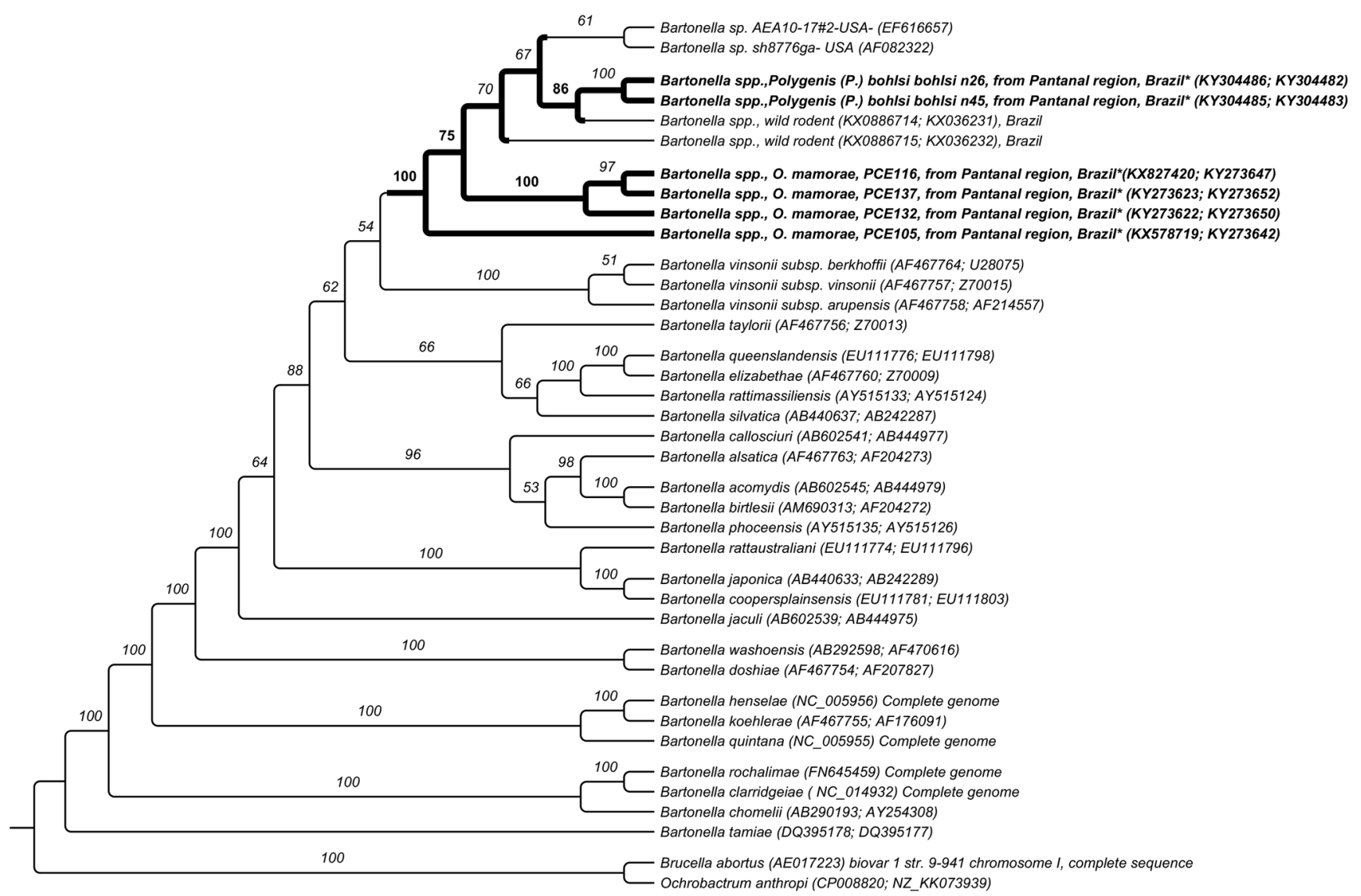

سبسسبس

Fig. 3 Phylogenetic tree constructed with 1245-bp Bartonella gltA+fts $Z$ sequences, using Bayesian method and GTR+G+I evolutionary model. Numbers at nodes correspond to Bayesian posterior probabilities over 50 ,

Bartonella sp. belonging to the phylogenetic group A for Cricetidae rodents (Sigmodon hispidus and Peromyscus leucopus) when compared to BALB/c mice and Wistar rats [35]. These partial results suggest that a genotype closely related to strain R-phy lor a possible new Candidatus Bartonella species is circulating among wild rodents from Brazil.

Although a genotype closely related to $B$. alsatica, B. pachyuromydis, B. birtlesii, B. acomydis, B. silvatica, and B. callosciuri was detected among T. fosteri rodents in Brazil based on the fts $Z$ and nuoG concatenated phylogenetic analysis, the identity values of fts $Z$ gene sequences were considerably low, which also suggest that a possible new Candidatus Bartonella species could be also circulating among T. fosteri rodents, based on the criteria for species definition in bacteriology [34]. Although the zoonotic potential of Bartonella belonging to phylogenetic group A, B. pachyuromydis, B. birtlesii, B. acomydis, $B$. silvatica, and $B$. callosciuriare still unknown, it is known that B. alsatica causes lymphadenitis [36] and endocarditis in humans [37], highlighting the importance of future studies to elucidate the ecological pathways involving this Bartonella genotype among rodents and vectors in Brazilian Pantanal region. using Ochrobactrum anthropi (CP008820, NZ_KK073939) and Brucella abortus (AE017223) as outgroups

Among the ectoparasites that infest wild rodents, fleas are considered the main vectors for Bartonella species [38]. Indeed, fleas are also considered important reservoirs for Bartonella [39]. Recently, B. clarridgeiae and B. henselae were detected in Ctenocephalides felis felis fleas collected from cats in the semi-arid region of Pernambuco, Brazil [6]. In the same study, B. rochalimae and B. vinsoni berkhofii were detected in Pulex irritans fleas collected from wild and domestic canids [6]. In the abovementioned study, although the sampled animals from which Bartonella positiveectoparasites were collected showed to be negative in PCR assays, they were seropositive to Bartonella spp. [6]. In the present study, a Bartonella closely related to R-phyl genotype was detected in both $O$. mamorae rodents and Polygenis (P.) bohlsi bohlsi fleas in Pantanal. Although Bartonella-positive fleas were collected from rodents showing negativity in PCR assays for Bartonella, the phylogenetic analysis showed that these two genotypes were closely related to each other. These results showed that the diagnosis of Bartonella spp. based only on PCR amplification of biological host's samples can show a lack of sensitivity, due to the fact the bacteremia found 


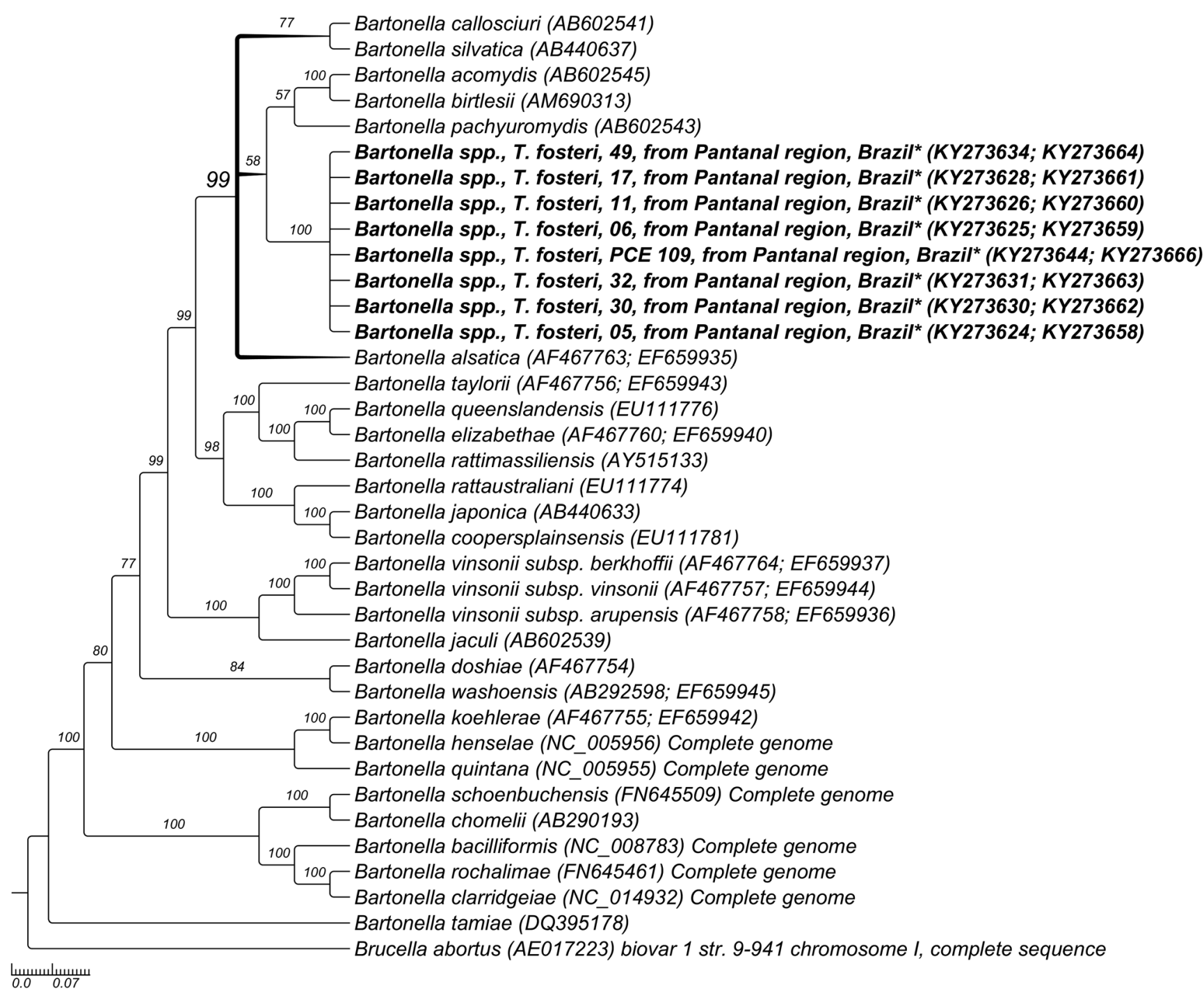

Fig. 4 Phylogenetic tree constructed with 820-bp Bartonella nuoG+ftsZ sequences, using Bayesian method and GTR+G+I and TrN+I+G evolutionary models. Numbers at nodes correspond to Bayesian posterior probabilities over 50, using Brucella abortus (AE017223) as outgroup

is usually low. However, the hemoconcentration of host blood meal in arthropods digestive tract could be responsible for the improvement in the sensitivity of molecular diagnosis of Bartonella. Therefore, the molecular assays performed on arthropods collected from hosts seem to reflect the epidemiological status of the bacteria among wild animals in nature in a better way. In addition to this, further investigations are needed in order to verify the vector competence of this flea species aiming at elucidating the epidemiology of these new Bartonella genotypes (or Candidatus species) in Brazil.

Although a previous study demonstrated the vectorial competence of Ixodes ricinus ticks in transmitting $B$. birtlesii to rodents [40], the biological role of ticks in the transmission of Bartonella in the environment has not yet been confirmed, and its epidemiological role is considered secondary [41]. In a previous study conducted in Pernambuco state, northeastern
Brazil [6], none of A. auricularium, A. dubitatum, $R$. sanguineus, and Argasidae tick specimens collected from wild and domestic animals showed positivity for Bartonella spp. in molecular assays. Considering that similar results were found in this present study, the importance of ticks in the bartonellosis epidemiology in Brazil remains unclear.

The Bartonella nucleotide diversity based on gltA sequences $(\mathrm{Pi}=0.028, \mathrm{hd}=0.8667)$ found in the present study was similar to that found in previous studies among rodents sampled in different biomes in Brazil $(\mathrm{Pi}=0.024)$ [7], Asia $(\mathrm{Pi}=0.02154)$, and North America $(\mathrm{Pi}=0.01427)$ [42], but higher than that found among $B$. grahamii genotypes detected in Myodes rutilus, Microtus fortis, and Apodemus agrariusrodentsin China $(\mathrm{Pi}=0.012)$ [42]. On the other hand, the found gltA diversity was lower than that found among Bartonella genotypes detected in Myodes glareolus rodents 
sampled in Paris, France $(\mathrm{Pi}=0.077)$ [43]. These findings reinforce the hypotheses that within the same gene $(\mathrm{gltA})$, recombination and mutation events may happen, promoting distinct haplotypes diversity in a certain population. In addition to this, the fts $Z$ nucleotide diversity observed $(\mathrm{Pi}=0.035)$ was also similar to that found among Bartonella genotypes detected in rodents in a previous study in Brazil $(\mathrm{Pi}=0.037)$ [7], but higher than those previously reported among B. grahamii genotypes detected in rodents in France ( $\mathrm{Pi}=$ 0.016) [43] and China $(\mathrm{Pi}=0.010)$ [42]. These results reveal some degree of Bartonella genetic diversity among the populations of wild rodents in Brazil.

Previously, Bartonella spp. were molecularly detected in six different species of wild felids, namely Leopardus wiedii, L. pardalis, Leopardus tigrinus, Leopardus geoffroyi, Puma yagouaroundi, and Panthera onca, maintained in captivity in Paraná state, southern Brazil [10]. Additionally, antibodies to B. clarridgeiae and Bartonella vinsonii subsp. berkhoffii were detected in four different species of wild canids, namely C. thous, Speothos venaticus, Canis lupus, and Lycalopex vetulus, maintained in captivity in the states of São Paulo and Mato Grosso, Brazil [11]. In the present study, none of the sampled wild carnivores showed presence of Bartonella DNA in blood samples. In a previous study involving freeroaming domestic cats in a zoo environment in Brazil [44], Bartonella DNA was detected in $30 \%$ of the sampled cats. Considering that domestic cats are the main reservoirs for $B$. henselae and B. clarridgeiae [2], the presence of infected cats in a zoo environment may have facilitated the Bartonella transmission to the wild carnivores maintained in captivity, which probably did not happen among wild canids and felids sampled in the present study, since they live free and the contact with domestic cats is scarce.

None of the domestic dogs sampled in the present study showed to be positive for Bartonella in qPCR assays. In Brazil, a low occurrence of Bartonella was reported in dogs from São Paulo (2/198) and Pernambuco (0/109) states [6, 9]. Besides, the diagnosis of Bartonella spp. based only on PCR amplification shows lack of sensitivity, due to the fact the bacteremia found in dogs may be usually low. A previous study showed that a combined approach using isolation culture-based growth medium, such as BAPGM, followed by PCR amplification, can provide a substantial improvement in chances of detection of $B$. henselae and $B$. vinsonii (berkhoffii) in the blood of naturally infected dogs [45].

In conclusion, the present study revealed that wild rodents in southern Pantanal region, Brazil, are exposed, at least, to two different genotypes (or Candidatus) of Bartonella spp. Considering the fact that some Bartonella genotypes found in this present study showed to be closely related to B. alsatica, a well-known zoonotic Bartonella species, studies aiming at assessing the transmission routes among rodents, involved vectors and the zoonotic potential of the isolates are much needed in order to prevent human cases of bartonellosis. Lastly, this study provided an evidence of the possible participation of Polygenis (P.) bohlsi bohlsi in Bartonella transmission cycles among wild rodents in Brazil. However, in order to confirm the competence of P. bohlsi fleas to transmit Bartonella, experimental studies must be performed.

Acknowledgments We are thankful to Fundação de Amparo à Pesquisa do Estado de São Paulo (FAPESP) and Conselho Nacional de Desenvolvimento Científico e Tecnológico $(\mathrm{CNPq})$ for the financial support to M.R. André (Process numbers \#2015/14896-1 and \#473575/ 2014-0, respectively) and for Doctorate Scholarship to K. C. M Sousa (Process \#2013/13186-5) and the Scientific Initiation Fellowship to R. B. Amaral (Process \# 2015/03262-1).

Compliance with ethical standards All animal captures were in accordance with the licenses obtained from the Brazilian Government Institute for Wildlife and Natural Resources Care (IBAMA) (license numbers 38145 and 38787-2) and was endorsed by the Ethics Committee of FCAV/UNESP University (Faculdade de Ciências Agrárias e Veterinárias, Universidade Estadual Paulista "Júlio de Mesquita Filho", Câmpus Jaboticabal) no. 006772/13.

\section{References}

1. Birtles RJ, Raoult D (1996) Comparison of partial citrate synthase gene $(\mathrm{glt} A)$ sequences for phylogenetic analysis of Bartonella species. Int. J. Syst. Bacteriol. 46:891-897

2. Breitschwerdt EB (2014) Bartonellosis: one health perspectives for an emerging infectious diseases. ILAR J. 55:46-58. https://doi.org/ 10.1093/ilar/ilu015

3. Gutiérrez R, Krasnov B, Morick D, Gottlieb Y, Khokhlova IS, Harrus S (2015) Bartonella infection in rodents and their flea Ectoparasites: an overview. Vector Borne Zoonotic Dis. 15:27-39. https://doi.org/10.1089/vbz.2014.1606

4. Costa F, Porter FH, Rodrigues G, Farias H, de Faria MT, Wunder EA, Osikowicz LM, Kosoy MY, Reis MG, Ko AI, Childs JE (2014) Infections by Leptospira interrogans, Seoul virus, and Bartonella spp. among Norway rats (Rattus norvegicus) from the urban slum environment in Brazil. Vector Borne Zoonotic Dis. 14:33-40. https://doi.org/10.1089/vbz.2013.1378

5. Favacho AR, Andrade MN, de Oliveira RC, Bonvicino CR, D'Andrea PS, de Lemos ER (2015) Zoonotic Bartonella species in wild rodents in the state of Mato Grosso do Sul, Brazil. Microbes Infect. 17:889-892. https://doi.org/10.1016/j.micinf. 2015.08.014

6. Fontalvo MC, Favacho ARM, Araujo AC, Santos NMD, Oliveira GMB, Aguiar DM, Lemos ERS, Horta MC (2017) Bartonella species pathogenic for humans infect pets, free-ranging wild mammals and their ectoparasites in the Caatinga biome, Northeastern Brazil: a serological and molecular study. Braz. J. Infect. Dis. 21:290-296. https://doi.org/10.1016/j.bjid.2017.02.002

7. Gonçalves LR, Favacho AR, Roque AL, Mendes NS, Fidelis Junior OL, Benevenute JL, Herrera HM, D'Andrea PS, de Lemos ER, Machado RZ, André MR (2016) Association of Bartonella species with wild and synanthropic rodents in different Brazilian biomes. Appl. Environ. Microbiol. 82:7154-7164. https://doi.org/10.1128/ AEM.02447-16

8. André MR, Dumler JS, Herrera HM, Gonçalves LR, de Sousa KC, Scorpio DG, de Santis AC, Domingos IH, de Macedo GC, 
Machado RZ (2015) Assessment of a quantitative 5' nuclease realtime PCR using the NADH dehydrogenase gamma subunit (nuoG) for Bartonella species in domiciled and stray cats in Brazil. J. Feline Med. Surg. 18:783-900. https://doi.org/10.1177/ $1098612 X 15593787$

9. Diniz PP, Maggi RG, Schwartz DS, Cadenas MB, Bradley JM, Hegarty B, Breitschwerdt EB (2007) Canine bartonellosis: serological and molecular prevalence in Brazil and evidence of coinfection with Bartonella henselae and Bartonella vinsonii subsp. berkhoffii. Vet. Res. 38:697-710. https://doi.org/10.1051/vetres: 2007023

10. Guimarães AM, Brandão PE, Moraes W, Kiihl S, Santos LC, Filoni C, Cubas ZS, Robes RR, Marques LM, Neto RL, Yamaguti M, Oliveira RC, Catão-Dias JL, Richtzenhain LJ, Messick JB, Biondo AW, Timenetsky J (2010) Detection of Bartonella spp in neotropical felids and evaluation of risk factors and hematological abnormalities associated with infection. Vet. Microbiol. 142:346351. https://doi.org/10.1016/j.vetmic.2009.10.002

11. Fleischman DA, Chomel BB, Kasten RW, André MR, Gonçalves LR, Machado RZ (2015) Bartonella clarridgeiae and Bartonella vinsonii subsp. berkhoffii exposure in captive wild canids in Brazil. Epidemiol. Infect. 143:573-577. https://doi.org/10.1017/ S0950268814001277

12. Sousa KCM, Fernandes MP, Herrera HM, Benevenute JL, Santos FM, Rocha FL, Barreto WTG, Macedo GC, Campos JB, Martins TF, Pinto PCEA, Barros-Battesti D, Piranda EM, Cançado PHD, Machado RZ, André MR (2017) Molecular detection of Hepatozoon spp. in domestic dogs and wild mammals in southern Pantanal, Brazil with implications in the transmission route. Vet. Parasitol. 237:37-46. https://doi.org/10.1016/j.vetpar.2017.02.023.

13. Sousa KCM, Herrera HM, Secato CT, Oliveira ADV, Santos FM, Rocha FL, Barreto WTG, Macedo GC, de Andrade Pinto PCE, Machado RZ, Costa MT, André MR (2017) Occurrence and molecular characterization of hemoplasmas in domestic dogs and wild mammals in a Brazilian wetland. Acta Trop. 171:172-181. https:// doi.org/10.1016/j.actatropica.2017.03.030

14. Sousa KCM, Fernandes MP, Herrera HM, Freschi CR, Machado RZ, André MR (2017) Diversity of piroplasmids among wild and domestic mammals and ectoparasites in Pantanal wetland, Brazil. Ticks Tick Borne Dis. in press. doi: https://doi.org/10.1016/j.ttbdis. 2017.09.010

15. Onofrio VC, Labruna MB, Pinter A, Giacomin FG, Barros-Battesti DM (2006) Comentários e chaves para as espécies do gênero Amblyomma. In: Barros-Battesti DM, Arzua M, Bechara GH (eds) Carrapatos de importância médico-veterinária da região neotropical: um guia ilustrado para identificação de espécies. Vox/ ICTTD-3/Butantan, São Paulo, pp 53-113

16. Martins TF, Barbieri AR, Costa FB, Terassini FA, Camargo LM, Peterka CR, de C Pacheco R, Dias RA, Nunes PH, Marcili A, Scofield A, Campos AK, Horta MC, Guilloux AG, Benatti HR, Ramirez DG, Barros-Battesti DM, Labruna MB (2016) Geographical distribution of Amblyomma cajennense (sensu lato) ticks (Parasitiformes: Ixodidae) in Brazil, with description of the nymph of A. cajennense (sensu stricto). Parasit. Vectors 9:186. https://doi.org/10.1186/s13071-016-1460-2

17. Martins TF, Onofrio VC, Barros-Battesti DM (2010) Nymphs of the genus Amblyomma (Acari: Ixodidae) of Brazil: descriptions, redescriptions, and identification key. Ticks Tick Borne Dis 1:7599. https://doi.org/10.1016/j.ttbdis.2010.03.002

18. Linardi PM, Guimarães LR (2000) Sifonápteros do Brasil. Museu de Zoologia USP/FAPESP, São Paulo

19. Birkenheuer AJ, Levy MG, Breitschwerdt EB (2003) Development and evaluation of a seminested PCR for detection and differentiation of Babesia gibsoni (Asian genotype) and B. canis DNA in canine blood samples. J Clinic Microbiol 41:4172-4177. https:// doi.org/10.1128/JCM.41.9.4172-4177.2003
20. Black WC, Piesman J (1994) Phylogeny of hard- and soft-tick taxa (Acari: Ixodida) based on mitochondrial 16S rDNA sequences. Proc. Natl. Acad. Sci. U. S. A. 91:10034-10038

21. Folmer O, Black M, Hoeh W, Lutz R, Vrijenhoek R (1994) DNA primers for amplification of mitochondrial cytochrome $\mathrm{c}$ oxidase subunit I from diverse metazoan invertebrates. Mol. Mar. Biol. Biotechnol. 3:294-299

22. Billeter SA, Gundi VA, Rood MP, Kosoy MY (2011) Molecular detection and identification of Bartonella species in Xenopsylla cheopis fleas (Siphonaptera: Pulicidae) collected from Rattus norvegicus rats in Los Angeles, California. Appl Environ 77: 7850-7852. https://doi.org/10.1128/AEM.06012-11

23. Colborn JM, Kosoy MY, Motin VL, Telepnev MV, Valbuena G, Myint KS, Fofanov Y, Putonti C, Feng C, Peruski L (2010) Improved detection of Bartonella DNA in mammalian hosts and arthropod vectors by real-time PCR using the NADH dehydrogenase gamma subunit (nuoG). J. Clin. Microbiol. 48:4630-4633. https://doi.org/10.1128/JCM.00470-10

24. Paziewska A, Harris PD, Zwolińska L, Bajer A, Siński E (2011) Recombination within and between species of the alpha proteobacterium Bartonella infecting rodents. Microb. Ecol. 61: 134-145. https://doi.org/10.1007/s00248-010-9735-1

25. Ewing B, Green P (1998) Base-calling of automated sequencer traces using phred. II. Error probabilities. Genome Res. 8:186194. https://doi.org/10.1101/gr.8.3.186

26. Bell TG, Kramvis A (2013) Fragment merger: an online tool to merge overlapping long sequence fragments. Viruses 5:824-833. https://doi.org/10.3390/v5030824

27. Katoh K, Standley DM (2013) MAFFT multiple sequence alignment software version 7: improvements in performance and usability. Mol Biol Evol 30:772-780. https://doi.org/10.1093/molbev/ mst010

28. Darriba D, Taboada GL, Doallo R, Posada D (2012) jModelTest 2: more models, new heuristics and parallel computing. Nat. Methods 9:772. https://doi.org/10.1038/nmeth.2109

29. Posada D, Buckley TR (2004) Model selection and model averaging in phylogenetics: advantages of akaike information criterion and bayesian approaches over likelihood ratio tests. Syst. Biol. 53:793-808

30. Ronquist F, Huelsenbeck JP (2003) MrBayes 3: Bayesian phylogenetic inference under mixed models. Bioinformatics 19:1572-1574

31. Thompson JD, Higgins DG, Gibson TJ (1994) CLUSTAL W: improving the sensitivity of progressive multiple sequence alignment through sequence weighting, position specific gap penalties and weight matrix choice. Nucleic Acids Res. 22:4673-4680

32. Librado P, Rozas J (2009) DnaSP v5: a software for comprehensive analysis of DNA polymorphism data. Bioinformatics 25:14511452. https://doi.org/10.1093/bioinformatics/btp187

33. Abbot P, Aviles AE, Eller L, Durden LA (2007) Mixed infections, cryptic diversity, and vector-borne pathogens: evidence from Polygenis fleas and Bartonella species. Appl. Environ. Microbiol. 73:6045-6052. https://doi.org/10.1128/AEM.00228-07

34. La Scola, Zeaiter Z, Khamis A, Raoult D (2003) Gene-sequencebased criteria for species definition in bacteriology: the Bartonella paradigm. Trends Microbiol 11:318-321

35. Kosoy MY, Saito EK, Green D, Marston EL, Jones DC, Childs JE (2000) Experimental evidence of host specificity of Bartonella infection in rodents. Comp. Immunol. Microbiol. Infect. Dis. 23:221238. https://doi.org/10.1016/S0147-9571(99)00075-2

36. Angelakis E, Lepidi H, Canel A, Rispal P, Perraudeau F, Barre I, Rolain JM, Raoult D (2008) Human case of Bartonella alsatica lymphadenitis. Emerg. Infect. Dis. 14:1951-1953. https://doi.org/ 10.3201/eid1412.080757

37. Jeanclaude D, Godmer P, Leveiller D, Pouedras P, Fournier PE, Raoult D, Rolain JM (2009) Bartonella alsatica endocarditis in a 
French patient in close contact with rabbits. Clin. Microbiol. Infect. 15:110-111. https://doi.org/10.1111/j.1469-0691.2008.02187.x

38. Tsai YL, Chang CC, Chuang ST, Chomel BB (2011) Bartonella species and their ectoparasites: selective host adaptation or strain selection between the vector and the mammalian host? Comp. Immunol. Microbiol. Infect. Dis. 34:299-314. https://doi.org/10. 1016/j.cimid.2011.04.005

39. Deng H, Le Rhun D, Buffet JP, Cotté V, Read A, Birtles RJ, Vayssier-Taussat M (2012) Strategies of exploitation of mammalian reservoirs by Bartonella species. Vet. Res. 43:15. https://doi.org/10. 1186/1297-9716-43-15

40. Reis C, Cote M, Le Rhun D, Lecuelle B, Levin ML, VayssierTaussat M, Bonnet SI (2011) Vector competence of the tick Ixodes ricinus for transmission of Bartonella birtlesii. PLoS Negl. Trop. Dis. 5:e1186. https://doi.org/10.1371/journal.pntd.0001186

41. Harrison A, Bown KJ, Montgomery WI, Birtles RJ (2012) Ixodes ricinus is not an epidemiologically relevant vector of Bartonella species in the wood mouse (Apodemus sylvaticus). Vector Borne Zoonotic Dis 12:366-371. https://doi.org/10.1089/vbz.2011.0807

42. Li DM, Hou Y, Song XP, YQ F, Li GC, Li M, Eremeeva ME, HX W, Pang B, Yue YJ, Huang Y, Lu L, Wang J, Liu QY (2015) High prevalence and genetic heterogeneity of rodent-borne Bartonella species on Heixiazi Island, China. Appl. Environ. Microbiol. 81: 7981-7992. https://doi.org/10.1128/AEM.02041-15

43. Buffet JP, Pisanu B, Brisse S, Roussel S, Félix B, Halos L, Chapuis JL, Vayssier-Taussat M (2013) Deciphering Bartonella diversity, recombination, and the host specificity in a rodent community. PLoS One 8:e68956. https://doi.org/10.1371/journal.pone.0068956

44. André MR, Baccarim Denardi NC, Marques de Sousa KC, Gonçalves LR, Henrique PC, Grosse Rossi Ontivero CR, Lima Gonzalez IH, Cabral Nery CV, Fernandes Chagas CR, Monticelli C, Alexandre de Santis AC, Machado RZ (2014) Arthropod-borne pathogens circulating in free-roaming domestic cats in a zoo environment in Brazil. Ticks Tick Borne Dis 5:545-551. https://doi.org/ 10.1016/j.ttbdis.2014.03.011

45. Duncan AW, Maggi RG, Breitschwerdt EB (2007) A combined approach for the enhanced detection and isolation of Bartonella species in dog blood samples: pre-enrichment liquid culture followed by PCR and subculture onto agar plates. J. Microbiol. Methods 69:273-281. https://doi.org/10.1016/j.mimet.2007.01.010 